\title{
The Analysis of Macroeconomic Factors Affecting the International Tourist Arrivals in Thailand
}

\author{
Miss. Lu Liu ${ }^{1}$, Jirakom Sirisrisakulchai ${ }^{1}$ and Jianxu Liu ${ }^{1}$
}

\begin{abstract}
In this paper, we investigated the macroeconomic factors affecting in international tourist arrivals in Thailand. We believed the macroeconomic factors, the tourism-specific price, CCI and unemployment rate of origin countries will impact on Thailand inbound tourism demand. We use the data from January 2000 to December 2015, China, Japan, Korea, Russia, UK, US were selected to be 6 origin countries. The results found the macroeconomic factors CCI had impact in tourist arrivals from China and Japan. The unemployment rate had influence in tourist arrivals from Russia. And both CCI and unemployment rate affected the tourist arrivals from US. The tourism-specific price had no significant impact in tourist arrivals from the origin countries. In this research the co-integration analysis was used to investigate the causal relationship between macroeconomic factors and the international tourist arrivals.
\end{abstract}

Keywords-Macroeconomic factors, International tourist arrivals, VAR model, VECM model

\section{INTRODUCTION}

$\mathrm{T}$ OURISM as early as the beginning of 1990s has developed into more than the oil industry and the automotive industry in the world's largest industry. At the same time, tourism is one of an important strategic, pillar and comprehensive industry of the sustained rapid and stable growth world economy. Nowadays, with the development of economic globalization and the integration of the world economy, the tourism industry in the world has entered a golden age of rapid development. In the year 2011, the World Travel \& Tourism Council released the "2011 2021 Tourism Economic Impact Report" mentioned, despite the world economic growth has encountered many challenges and uncertainties, tourism has been one of the fastest growing sectors, and has become the main force to promote economic and employment growth. Expected in the next 10 years, the world tourism industry's contribution to global GDP will reach $4.2 \%$ annually, the total amount will reach about $\$ 9.2$ trillion and will create approximately 65 million jobs.

Thailand as a tourist country, the development of tourism has led to Thailand's economic development. International

Lu Liu, Faculty of Economics, Chiang Mai University, Chiang Mai 50200, Thailand.

Jirakom Sirisrisakulchai, Faculty of Economics, Chiang Mai University, Chiang Mai 50200, Thailand.

Jianxu Liu, 1Faculty of Economics, Chiang Mai University, Chiang Mai 50200, Thailand. arrivals to Thailand show a significant rise from 2000. In 2000, the number of tourists in Thailand was about 9.5 million, the tourism arrivals reached 26.55 million in 2013, an increase of $165 \%$. From the year 2000 to 2014, the average annual growth rate of tourist's arrivals was around $7.75 \%$. In 2015, the international arrivals growth rate reached $20.44 \%$, total arrivals were 29.88 million. That was a dramatically growth. In 2015, the direct contribution of tourism reached $\$ 36.4$ billion, share $7.18 \%$, the total contribution reached $\$ 81.6$ billion, share $20.8 \%$. That was a crucial part of the nation economy. Therefore, the analysis of tourism demand has crucial significance in establishing tourism development strategies, promoting the international competitiveness of tourism industry, and moving to a powerful tourism country.

The paper is organized as follows: Section 2 is the brief literature reviews of this study, section 3 presents the econometric methodology, section 4 describes the results and discussion of the research.

\section{LITERATURE REVIEW}

All Tourism demand modeling studies have had a half-acentury history. The earliest researches can be retrospected to the 1960s, especially pioneered by Guthrie (1961). Since then the research of this field has developed rapidly, in terms of the diversity of research interests, the depth of theoretical foundations, and advances in research methodologies ( $\mathrm{Li}$ et al. 2005). The developments of tourism demand research were reviewed in a great number of literature reviews. In earlier reviews such as Archer (1980, 1987), Bar-On (1984) and Vanhove (1980), considerable attention was devoted to explaining the techniques applicable to tourism demand forecasting. More recently Crouch conducted a series of more comprehensive reviews covering about 80 econometric studies during the period 1961-1993. In particular, Crouch investigated various inter-study differences, principally with respect to demand elastics. Similarly, Lim (1997a, 1997b, 1999) reviewed 100 papers published during the period 19611994. Attention was paid to the choice of dependent and explanatory variables, functional specifications and data in use. Witt and Witt (1995) reviewed 40 empirical studies published prior to 1992, with a particular emphasis on empirical comparisons of forecasting accuracy among different approaches. Li et al. (2005) an Song and Li (2008) reviewed the most recent 84 and 121 tourism demand studies respectively. They identified the latest methodological developments and emerging trends in this field of research. 
Because of the lack of tourism-specific theory, almost all empirical models borrow heavily from neoclassical theory and basic consumer theory (Varian, 1992) which assumed that the optimal consumption level depend on the consumer's income, the price of good, the prices of related goods and other factors. A lot of researchers use the econometric methods study in tourism demand. Allen et al. (2009) did the paper about investigate the short- and long-run causal relationships between economic factors and interstate tourism demand in Australia. Using a cointegration approach, this study discovers two distinct results. First, household income, accommodation prices, price of recreation and restaurants and domestic airfares have significant impacts on the demand in the shortrun. Second, some of the long-run economic coefficient show incorrect signs, which contradict the theory of consumer demand. Zhong Wang (2010) used a VAR (vector autoregression) model, in which the Granger Causality Test, the Impulse Response Function and the Variance Decomposition are adopted in explored the factors affecting the growth of Chinese domestic tourism arrivals from 1985 to 2007 . The result of his test showed that in the short run, the main factor influencing domestic tourism arrivals' growth is its own growth inertia, in the middle-to-long run, the main factor is income, and in the long run the main factor is transportation. And leave policy is not the major factor affecting domestic tourism arrivals' growth.

In this paper the macroeconomic factor may affect tourist arrivals we considered the consumer confidence indicator(CCI), the tourism-specific prices, unemployment rate. The consumer confidence indicator(CCI) as providing inferences on the degree of uncertainty associated with future economic conditions in the country of origin. According to Ludvigson (2004), high consumer confidence reflects the reduced uncertainty on future economic conditions, which means reduced the precautionary savings and increased the present consumption. And research shows that the exchange rate adjusted CPI, either alone or together with a separate exchange rate variable, is a good index for tourism cost, while the exchange rate itself is not (Martin and Witt, 1987). That defined was the tourism-specific prices. Finally we fund that

TABLE

UNIT ROOT TEST RESULTS

\begin{tabular}{|c|c|c|c|c|c|c|c|c|}
\hline Destination & & & Levels & & & First & Difference & \\
\hline Variables & Arrivals & CCI & $\mathrm{P}$ & UN & Arrivals & CCI & $\mathrm{P}$ & UN \\
\hline China & 0.7787 & 0.5204 & 0.8307 & 0.8995 & 0.0000 & 0.0000 & 0.0000 & 0.0000 \\
\hline Japan & 0.7056 & 0.6820 & 0.8825 & 0.3084 & 0.0000 & 0.0000 & 0.0000 & 0.0000 \\
\hline Korea & 0.9178 & 0.6421 & 0.7003 & 0.3596 & 0.0000 & 0.0000 & 0.0000 & 0.0000 \\
\hline Russia & 0.9691 & 0.5291 & 0.0018 & 0.4132 & 0.0016 & 0.0000 & 0.0000 & 0.0097 \\
\hline UK & 0.9997 & 0.7614 & 0.5377 & 0.5478 & 0.0000 & 0.0000 & 0.0000 & 0.0000 \\
\hline US & 0.9490 & 0.5144 & 0.5876 & 0.5825 & 0.0000 & 0.0000 & 0.0000 & 0.0000 \\
\hline
\end{tabular}

Table I is uint root test results, which showed most between macroeconomic factors and tourist arrivals. For countries' variable not stationary at levels but stationary at first difference, then this will consider to use cointegration analysis.

Cointegration would determine the types of model (VAR/ VECM) that we may then use to tell the direction of causality

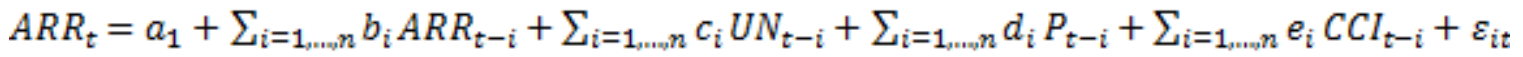

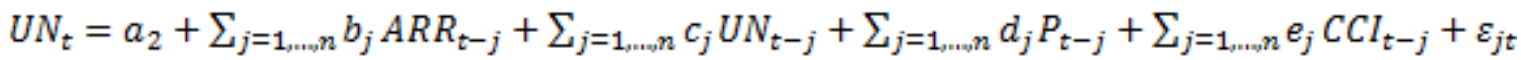

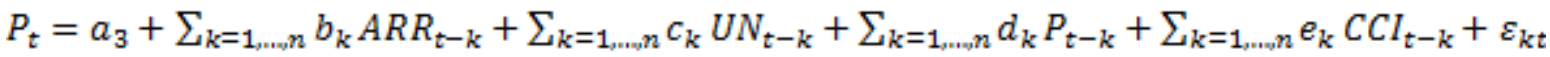


(4)

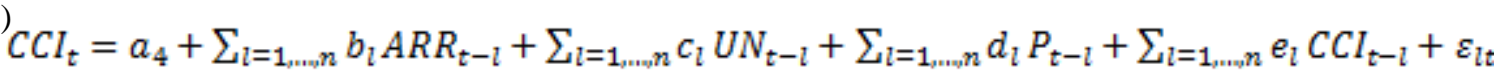

where the $A R R_{t}$ is the tourist arrivals from origin country to Thailand, $U N_{t}$ is the unemployment rate of origin country, $P_{t}$ is the tourism-specific prices in destination country by consumers from origin country, $\mathrm{CCI}_{t}$ is the consumer confidence indicator of origin country.

\section{Cointegration Test}

Cointegration test is meant to reveal the existence of long run equilibrium relationship between the variables. A lack of cointegration suggests that such variable have no long run equilibrium relationship and in principle, they can wander arbitrarily far away from each other (Dickey, Jansen, \& Fuller, 1991). The hypothesis that tests this is the null of noncointegration against an alternative that cointegration exists. This uses the Johansen (1988) maximum likelihood ratio test and looks at two test statistics (Johansen \& Juselius, 1990), namely, the trace statistics and the maximum eigenvalue statistics, as follows:

$$
\lambda_{\text {trace }}=-T \sum_{i=r+1}^{n} \ln \left(1-\hat{\lambda}_{i}^{2}\right)
$$

where $\lambda_{i}$ is the estimated value of the ordered eigenvalue obtained from the estimated matrix. $\mathrm{T}$ is the number of the observations after the lag adjustment, $r$ is the number of distinct co-integration vectors.

$$
\lambda_{\max }(r / r+1)=-T \ln \left(1-\lambda_{r+1}\right)
$$

where $\lambda_{i}$ is the estimated value of the ordered eigenvalue obtained from the estimated matrix. $\mathrm{T}$ is the number of the observations after the lag adjustment, $r$ is the number of distinct co-integration vectors.

Table II is the cointegration test results of study. From the results of the cointegration test we know some countries there was long-run relationship between macroeconomic factors and tourist arrivals.
TABLE II: COINTEGRATION TEST RESULTS

\begin{tabular}{llllll}
\hline \hline Countries & $\begin{array}{l}\text { Null } \\
\text { hypothesis }\end{array}$ & $\begin{array}{l}\text { Trace } \\
\text { statistics }\end{array}$ & Prob.** & $\begin{array}{l}\text { Max } \\
\text { Eigenvalue }\end{array}$ & Prob.** \\
\hline China & $\mathrm{H}_{0}: \mathrm{r}=0$ & 48.78276 & 0.0408 & 20.38255 & 0.3153 \\
& $\mathrm{H}_{0}: \mathrm{r} \leq 1$ & 28.40021 & 0.0718 & 15.49214 & 0.2559 \\
& $\mathrm{H}_{0}: \mathrm{r} \leq 2$ & 12.90807 & 0.1182 & 12.40791 & 0.0963 \\
Japan & $\mathrm{H}_{0}: \mathrm{r}=0$ & 77.27001 & 0.0000 & 41.03743 & 0.0005 \\
& $\mathrm{H}_{0}: \mathrm{r} \leq 1$ & 36.23258 & 0.0079 & 28.23651 & 0.0042 \\
& $\mathrm{H}_{0}: \mathrm{r} \leq 2$ & 7.996079 & 0.4658 & 6.978985 & 0.4916 \\
\multirow{3}{*}{ Korea } & $\mathrm{H}_{0}: \mathrm{r}=0$ & 65.36773 & 0.0005 & 29.35206 & 0.0294 \\
& $\mathrm{H}_{0}: \mathrm{r} \leq 1$ & 36.01567 & 0.0084 & 23.23996 & 0.0249 \\
& $\mathrm{H}_{0}: \mathrm{r} \leq 2$ & 12.77572 & 0.1233 & 11.20849 & 0.1441 \\
UK & $\mathrm{H}_{0}: \mathrm{r}=0$ & 73.46745 & 0.0000 & 39.49941 & 0.0009 \\
& $\mathrm{H}_{0}: \mathrm{r} \leq 1$ & 33.96803 & 0.0156 & 24.85564 & 0.0142 \\
& $\mathrm{H}_{0}: \mathrm{r} \leq 2$ & 9.112395 & 0.3551 & 7.389514 & 0.4441 \\
& $\mathrm{H}_{0}: \mathrm{r}=0$ & 86.27599 & 0.0000 & 44.64463 & 0.0001 \\
US & $\mathrm{H}_{0}: \mathrm{r} \leq 1$ & 41.63136 & 0.0014 & 30.38193 & 0.0019 \\
& $\mathrm{H}_{0}: \mathrm{r} \leq 2$ & 11.24943 & 0.1966 & 9.324130 & 0.2602 \\
\hline \hline
\end{tabular}

\section{D.VECM Model}

An error correction model belongs to a category of multiple time series models most commonly used for data where the underlying variables have a long-run stochastic trend, as cointegration. ECMs are a theoretically-driven approach useful for estimating both short-term and long-term effects of one time series on another. The term error-correction relates to the fact that last-periods deviation from a long-run equilibrium, the error, influences its short-run dynamics. Thus ECMs directly estimate the speed at which a dependent variable returns to equilibrium after a change in other variables. If the variables are cointegrated, the VECM model would be applied as follows:

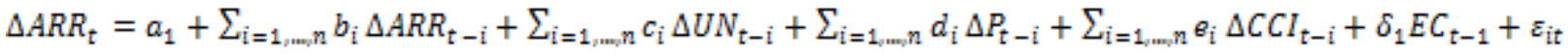

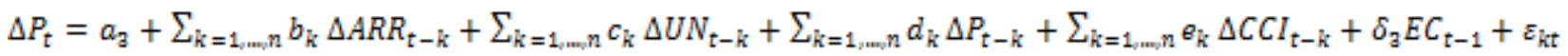

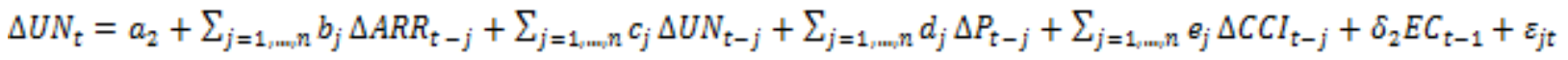

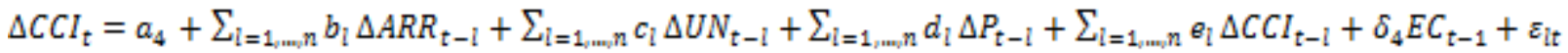

where the $A R R_{t}$ is the tourist arrivals from origin country to Thailand, $U N_{t}$ is the unemployment rate of origin country, $P_{t}$ is the tourism-specific prices in destination country by consumers from origin country, $\mathrm{CCI}_{t}$ is the consumer confidence indicator of origin country. EC is error correction term that the estimated residual from the cointegration regression.

\section{RESUltS AND DisCUSSION}

In this study first step was to examine the stationary of the time series variables, and ADF unit root test was used. The results of table 1 indicated that no time series variables stationary at level except the tourism specific price of Russia and other 5 countries' variables stationary at I(1). So for Russia we did the first difference of variables and VAR was used. The other 5 countries we did the cointegration test. The 
results of cointegration test table 2 showed that time series variables of Japan, Korea, UK, US are cointegrated, the longrun relationship may exist among them. For China we did the same with Russia.

TABLE III:

VAR GRANGER CAUSALITY TEST

\begin{tabular}{cccc}
\hline \hline Independent Variables & CCI & P & UN \\
\hline Arrivals from China & 0.0034 & 0.2944 & 0.5342 \\
Arrivals from Russia & 0.1930 & 0.7650 & 0.0011 \\
\hline \hline
\end{tabular}

TABLE IV:

VECM GRANGER CAUSALITY TEST

\begin{tabular}{cccc}
\hline \hline Independent Variables & CCI & P & UN \\
\hline Arrivals from Japan & 0.0928 & 0.2018 & 0.8055 \\
Arrivals from Korea & 0.5621 & 0.1865 & 0.6185 \\
Arrivals from UK & 0.5571 & 0.1225 & 0.3999 \\
Arrivals from US & 0.0034 & 0.8228 & 0.0768 \\
\hline \hline
\end{tabular}

The estimated results of VAR in table III indicated the CCI was the factor affected the tourist arrivals from China and the unemployment rate was the factor affected the tourist arrivals from Russia, both in the short-run. The estimated results of VECM in table IV showed the factor CCI had influence in tourist arrivals from Japan in the long-run relationship. The $\mathrm{CCI}$ and unemployment rate showed a significant influence in the tourist arrivals from US in the long-run relationship. Finally, the table 4 showed the macroeconomic factors had no significant influence in tourist arrivals from Korea and UK. In a word, the results indicated the CCI and unemployment rate could be the factors affecting the tourism industry. As we mentioned the high consumer confidence reflects the reduced uncertainty on future economic conditions, which means reduced the precautionary savings and increased the present consumption. And if the country has high unemployment rate which citizen may not have higher passion to travel.

\section{V.CONCLUSION}

This study has examined the relationship between macroeconomic factors of origin countries and tourist arrivals in Thailand used the data from January, 2000 to December, 2015. This analysis is seemed to be vital in tourism demand analyzing in Thailand. Though there are a lot of paper did the researches about the tourism demand in Thailand, this paper is the first paper considered the macroeconomic factor CCI as one of the factors may affected the international tourist arrivals in Thailand. And the results indicated the CCI and unemployment rate had influence in tourist arrivals. The paper may give the tourism policy maker suggestions that CCI and unemployment rate of origin countries could be the factors impact the tourism demand in Thailand. And when the policy maker doing the plan of the next year, these two factors could be good indicators to be considered.

\section{ACKNOWLEDGEMENTS}

I would like to express my special thanks of gratitude to my advisor Jirakom Sirisrisakulchai and my co-advisor Jianxu Liu who have provided me with valuable guidance in the writing of this paper. Without their enlightening instruction, impressive kindness and patience, I could not have completed this paper. Last but not least, I would like to show my deepest gratitude to Faculty of Economics, Chiang Mai University, which gave me the great support to do the research, provided me a great of data, materials to study.

\section{REFERENCES}

[1] Abascal, T.E., M. Fluker, and M. Jiang, Domestic demand for Indigenous tourism in Australia: understanding intention to participate. Journal of Sustainable Tourism, 2016. 24(8-9): p. 1350-1368. https://doi.org/10.1080/09669582.2016.1193187

[2] Agyeiwaah, E. and R. Adongo, Identifying core determinants of tourism demand in Hong Kong inbound markets. International Journal of Tourism Cities, 2016. 2(1): p. 17-28. https://doi.org/10.1108/IJTC-07-2015-0015

[3] Arana, J.E. and C.J. Leon, The impact of terrorism on tourism demand. Annals of Tourism Research, 2008. 35(2): p. 299-315. https://doi.org/10.1016/j.annals.2007.08.003

[4] Bento, J.P.C., The determinants of international academic tourism demand in Europe. Tourism Economics, 2014. 20(3): p. 611-628. https://doi.org/10.5367/te.2013.0293

[5] Blanchflower, D.G., Unemployment, well-being, and wage curves in Eastern and Central Europe. Journal of the Japanese and International Economies, 2001. 15(4): p. 364-402. https://doi.org/10.1006/jjie.2001.0485

[6] Bram, J. and S.C. Ludvigson, Does consumer confidence forecast household expenditure? A sentiment index horse race. 1997.

[7] Gounopoulos, D., D. Petmezas, and D. Santamaria, Forecasting tourist arrivals in Greece and the impact of macroeconomic shocks from the countries of tourists' origin. Annals of Tourism Research, 2012. 39(2): p. 641-666.

[8] Kim, S. and H. Song, Analysis of inbound tourism demand in South Korea: a cointegration and error correction approach. Tourism Analysis, 1998. 3(1): p. 25-41.

[9] Ouerfelli, C., Co-integration analysis of quarterly European tourism demand in Tunisia. Tourism Management, 2008. 29(1): p. 127-137. https://doi.org/10.1016/j.tourman.2007.03.022

[10] Untong, A., ASEAN Long-Run Tourism Elasticity Demand in Thailand. Applied Economics Journal, 2015. 22(2): p. 77-101.

[11] Wang, Y.S., The impact of crisis events and macroeconomic activity on Taiwan's international inbound tourism demand. Tourism Management, 2009. 30(1): p. 75-82. https://doi.org/10.1016/j.tourman.2008.04.010

[12] Wang, Z., Factors that Influence the Growth of Chinese Domestic Tourism Arrivals (1985-2007) - An Empirical Research Based on the VAR Model. Asia Pacific Journal of Tourism Research, 2010. 15(4): p. 449-459.

https://doi.org/10.1080/10941665.2010.520947 